\title{
Considerations Regarding the Relation Between Meadow and Animal in Baisoara Commune
}

\author{
Mirela Felicia CIREBEA, Ioan ROTAR*, Roxana Mirela VIDICAN, Florin Simion PĂCURAR \\ University of Agricultural Science and Veterinary Medicine, Cluj Napoca, No 3-5, Calea Manas- \\ tur Street, 400372 Cluj-Napoca, Romania \\ *corresponding author: rotarioan52@yahoo.fr
}

Bulletin USAMV series Agriculture 71(2)/2014

Print ISSN 1843-5246; Electronic ISSN 1843-5386

DOI 10.15835/buasvmcn-agr: 10886

\begin{abstract}
The mountains formed of the oldest times an environment inhabited by the humans. (All over the European mountains, mountain people have ensured that feed in the first place by agriculture focused on the animal husbandry especially ruminants. Increasing cattle, sheep and goats has been widespread concern in Europe with accents and northern temperate climate zones. Pastures have a very important role in mountain agriculture and are characterized mainly by small structures and low input systems. After 1990 the management of grassland systems in Romania has undergone of many important changes. This situation is mainly caused by the decreasing number of animals and by the diminished interest of people responsible on its management. In this tendency we can include the natural landscape of Apuseni Mountains, on which we focused all our attention and which, in fact represents the object of our study. The aim of this study was to evaluate the quality of mountain grassland reported of grazing capacity (grassland belongs to Baisoara commune, Apuseni Mountains) under the influence of the management applied, the level of anthropogenic and tradition influence. For these purposes, studies aimed to determine the floristic structure, the evolution of livestock and demographic tendency have been conducted. Vegetation study was made using Braun- Blanquét method. With the results obtained, vegetation coverage degree and grazing capacity were determinate and the direction in evolution of vegetation cover was established. For these we used data regarding the number of animals, as well as data about agricultural surfaces and demographic evolution. These were taken from the Agricultural Registers of Băisoara commune (data related to the number of animal and agricultural surfaces) and from The National Institute of Statistics (data about demographic evolution). The obtained results showed a close relationship between grassland status and the number of animals, which led us to the conclusion that the level of intensification of the crop system determines the direction of evolution.
\end{abstract}

Keywords: mountain area, vegetation cover, grassland systems management, number of animals.

\section{INTRODUCTION}

The mountain region which covers half the continent, is in a many ways vital importance for European population. The mountain areas are characterized by a permanent natural handicap due to the relief and the climatic restrictions of the economy and agricultural activities. (Potsch E. et al., 2011).

The Apuseni Mountains are part of the territories unequivocally affected by demographic, risk which translates to fast depopulation and irreversible structural disorder on the short and medium term.
The pastures have a very important role in mountain agriculture and are characterized mainly through small structures and low-input systems based on efficient use of internal resources for farming.

There is a difficult balance to protect the valued aspects of traditional mountain agriculture such as grazing, transhumance and biodiversity of grasslands, the need to ensure long-term competitiveness and a way of life for farming families compatible with XXI century. (HOPKINS, 2011). Mountain agriculture in Europe is facing many challenges. 
The abandonment areas less accessible and less productive is a threat that affects many parts of Europe. It is obvious that the work was abandoned agricolă randomly in the mountains of Eastern Europe after the fall of communism. An eloquent example of this is the Apuseni Mountains.

The aim of this study was to evaluate the quality of the pasture (which is part of Baisoara common, Apuseni Mountains), under the influence of applied management and level of anthropogenic influence.

\section{MATERIAL AND METHOD}

A specific farming system meets with many unique items in the Apuseni Mountains. In our study we examined specific aspects of Băisoara commune which is located in Cluj county and is representative of the area to which we refer.

Baisoara is situated in the Apuseni Mountains of north-east of Big Mountain and south of Gilaului Mountains in the hydrographic basin of Iara River.

The pedological substrate is included in Spodisoluri class with Prepodzoluri type (soil mainly characterized by low natural fertility and strong acidity).

The study area is characterized by a mountainous climate, which is, in fact, representative for all West and North-West regions of Romania. Thus the climate is very rough with long winter (the first frost occurs on the middle of September and lasts until April) and short summer, with abundant precipitation and a medium temperature for July month around $16,6^{\circ} \mathrm{C}$. The annual average temperature is between $2^{\circ} \mathrm{C}$ and $6^{\circ} \mathrm{C}$.
In order to fulfill the objectives proposed we used data regarding the demographic evolution (from The National Institute of Statistics) as well as data regarding the evolution of the number of animals and the agricultural surfaces (from the Agricultural Registers of Băisoara commune). The vegetation study was made Vegetation The study was made in several areas of Mountain Baisorii using Braun-Banquet method. This method involves the description of the vegetation from an area of 100 square meters. Vegetation structure and the percent of participation of the main species were undertaken by the researcher. With the results obtained we calculated the degree of vegetation coverage and the grazing capacity and we were able to underline the direction of this pasture evolution.

\section{RESULTS AND DISCUSSIONS}

The population of the commune decreased in time, attractiveness of commune for stability of population in the area is low, the economic causes, on the economical evolution of the commune which was unable to provide a minimum income for the inhabitants.

The mining exploitation Iara-Băişoara (have worked 1,700 employees) and the Institute of Geological design (there were 200 employees) gradually decreased mining activity, being completely closed in 2006 year. The Ecodesign institute was closed in 2000 year. Young people from the mountains gradually definitive leave the mountain for search of easier life and higher revenues with lower efforts in urban areas or

Tab. 1. The number of inhabitants of the Baisoara Commune 2013

\begin{tabular}{lc}
\hline Village & The number of inhabitants \\
\hline Săcel village & 407 \\
\hline Muntele Săcelului village & 47 \\
\hline Moara de Pădure village & 89 \\
\hline Frasinet village & 49 \\
\hline Muntele Cacovei village & 115 \\
\hline Muntele Filii village & 11 \\
\hline Muntele Bocului village & 56 \\
\hline Muntele Băișorii village & 279 \\
\hline Băișoara village & 1020 \\
\hline Total population in Băisoara commune & 2073 \\
\hline
\end{tabular}

Source: Local document of Baisoara commune, Cluj County, 2013; National Evaluation on the number of people and houses from Cluj area, 2013, Central department of statistics from Cluj-Napoca. 
Tab. 2. The number of animals in the Baisoara Commune 2013

\begin{tabular}{lccc}
\hline Village & Cattle & Sheep & Horses \\
\hline Săcel village & 84 & 1880 & 25 \\
\hline Muntele Săcelului village & 82 & 2 & 4 \\
\hline Moara de Pădure village & 25 & 0 & 21 \\
\hline Frasinet village & 50 & 0 & 14 \\
\hline Muntele Cacovei village & 190 & 150 & 12 \\
\hline Muntele Filii village & 30 & 0 & 10 \\
\hline Muntele Bocului village & 135 & 800 & 10 \\
\hline Muntele Băişorii village & 282 & 360 & 18 \\
\hline Băişoara village & 95 & 352 & 155 \\
\hline $\begin{array}{l}\text { Total number of animals in the } \\
\text { Băișoara Commune }\end{array}$ & 973 & 3544 & \\
\hline
\end{tabular}

Source: Statistic notebook of Baisoara Commune,2013; Central department of statistics from Cluj-Napoca; Local document of Baisoara Commune, Cluj County, 2013.

Tab. 3. Total area and the agricultural area in the Baisoara Commune 2013

\begin{tabular}{lccccc}
\hline Village & $\begin{array}{c}\text { The total } \\
\text { area } \\
\text { of the village [ha] }\end{array}$ & $\begin{array}{c}\text { Agricultural } \\
\text { area [ha] }\end{array}$ & $\begin{array}{c}\text { Arable } \\
\text { land [ha] }\end{array}$ & $\begin{array}{c}\text { Grassland } \\
\text { area [ha] }\end{array}$ & $\begin{array}{c}\text { Hayfields } \\
\text { area [ha] }\end{array}$ \\
\hline Săcel village & 1996 & 1244 & 40 & 729 & 475 \\
\hline Muntele Săceluluivillage & 664 & 228 & 6 & 125 & 97 \\
\hline Moara de Pădure village & 446 & 140 & 2 & 90 & 48 \\
\hline Frasinet village & 557 & 152 & 6 & 89 & 57 \\
\hline Muntele Cacovei village & 778 & 440 & 12 & 254 & 174 \\
\hline Muntele Filii village & 224 & 120 & 3 & 75 & 42 \\
\hline Muntele Bocului village & 333 & 324 & 6 & 190 & 128 \\
\hline Muntele Băișorii village & 1665 & 1655 & 15 & 960 & 680 \\
\hline Băișoara village & 4441 & 1981 & 34 & 688 & 599 \\
\hline Total surfaces Băisoara Commune & 11104 & 6284 & 124 & 3200 & 2300 \\
\hline
\end{tabular}

Source: Statistic notebook of Baisoara Commune,2013 , Central department of statistics from Cluj-Napoca ; Local document of Baisoara Commune, Cluj County, 2013.

Tab. 4. Floristic structure of Nardus stricta + Agrostis capillaris grassland

\begin{tabular}{lccc}
\hline Species & $\%$ & IS & $\%$ IS \\
\hline Nardus stricta & 50 & 0 & 0 \\
\hline Agrostis capillaris & 25 & 3 & 75 \\
\hline Festuca rubra & 15 & 3 & 45 \\
\hline Carex montana +Luzula campestris & 1 & 0 & 0 \\
\hline Hypericum perforatum & 4 & 0 & 2 \\
\hline Alchemilla vulgaris & 1 & 2 & 1 \\
\hline Filipendula hexapetala & 1 & 1 & 0 \\
\hline Vaccinium myrtillus & 1 & 0 & 0 \\
\hline Polytrichum commune & 1 & 0 & 0 \\
\hline Pteridium aquilinum & 1 & 0 &
\end{tabular}


other countries. This phenomenon with serious implications in the medium and long term.

In all nine villages that belong to the commune taken to be studied the number of inhabitants has decreased considerably. Along with decreasing population and the number of animals was reduced after 1990 mainly because of "age" population, with high aging and also due the inability to capitalize on secondary animal products (no milk collection units, lack of slaughterhouses, there are no slaughterhouse in Cluj county, and so on).

In agricultural systems continued decrease of agricultural lands (Table 3). One reason could be the rising fuel prices and the second reason could be the degree of aging of the population. Natural pedo-climatic conditions are less favorable for agricultural cultivation, being a limiting factor in terms of cultivated species. The cultivation of cereals (wheat, rye and corn) is possible only in areas at lower altitudes, while at high altitudes is grown only a few varieties of vegetables and potatoes.

The vegetation study resulted in 5 different types of grasslands, from which the most representative are Agrostis capillaries, Festuca rubra and Nardus stricta. All of them are included in the VIII class which describes a low quality grassland. The grassland type Nardus stricta +Agrostis capillaris is characterized by a floristic structure where Gramineae sp. are dominant $(90 \%)$ and by a coverage degree $(90 \%$, Table 4$)$.

Grazing capacity was calculated for each representative village from Baisoara commune (Table 5), for each kind of animal: sheep, cattle, horses (mentioned in Table 2). This parameter was calculated taking into account the total grassland surfacesand hayfields and the value of U.V.M./ surface (a value received as a result of the classification due to vegetation study; since it was included in VIII class the U.V.M. value is of 0,6 ).

Since immemorial times the mountain meadows have been intense exploited by the animal breeders who deforested woods for this purpose, after having maintained a proper loading with species and categories of animals to perpetuate the existence of herbaceous forage carpet.

The beginnings practicing transhumance is lost in the distant mists of time Dacian period. Many documents confirm this practicing, by the people from Transylvanians and Oltenia from mountains area. Transhumance started as a necessity profitable of breeding sheep, with the increasing number of animals and pre-mountain areas.

Transhumance is practiced in Apuseni Mountains, cattle and sheep breeding is based on the occupation of the locals, but the potential productive meadows and hayfields is greatly diminished, due to a low fertility soil and short vegetation period (5-6 months). It is clear that transhumance was not and is not a fad, is a way to life by which residents looking cheaper fodder resources in sufficient quantities for animals in summer time in the mountains. In spring time the inhabitants of the Mountain Baisorii village move to the mountains in summer stables for three months (June to September) with all their

Tab. 5. Grazing capacity and Cargo of animals in the 2013 year

\begin{tabular}{lcc}
\hline Village & $\begin{array}{c}\text { Grazing capacity* } \\
\text { [LU/Surface] }\end{array}$ & $\begin{array}{c}\text { Cargo of animal } \\
\text { [LU/Surface] }\end{array}$ \\
\hline Săcel Village & 722.4 & 350.4 \\
\hline Muntele Săcelului Village & 133.2 & 69.08 \\
\hline Moara de PădureVillage & 82.8 & 36.8 \\
\hline Frasinet Village & 87.6 & 51.2 \\
\hline Muntele Cacovei Village & 256.8 & 182.6 \\
\hline Muntele Filii Village & 70.2 & 32 \\
\hline Muntele Bocului Village & 190.8 & 228 \\
\hline Muntele Băișorii Village & 984 & 308.8 \\
\hline Băișoara Village & 772.2 & 139.68 \\
\hline Băișoara commune Total & 3300 & 1398.56 \\
\hline
\end{tabular}


Tab. 6. The practice of transhumance in Muntele Baisorii village

\begin{tabular}{|c|c|c|c|c|c|c|}
\hline Location & Year & $\begin{array}{c}\text { Families } \\
\text { who care } \\
\text { animals } \\
\end{array}$ & Cattle & Sheep & Horses & $\begin{array}{c}\text { Forested } \\
\text { Surface }\end{array}$ \\
\hline \multirow{2}{*}{ Gabriana } & 1990 & 15 & 65 & 35 & 8 & \multirow{2}{*}{$\begin{array}{c}\text {-forested } \\
35 \%\end{array}$} \\
\hline & 2014 & 4 & 15 & - & 1 & \\
\hline \multirow{2}{*}{ Crinţi } & 1990 & 8 & 50 & 60 & 2 & \multirow{2}{*}{$\begin{array}{l}\text { - forested } \\
70 \%\end{array}$} \\
\hline & 2014 & 3 & 23 & - & 1 & \\
\hline \multirow{2}{*}{ Izvorele } & 1990 & 9 & 63 & 160 & 6 & \multirow{2}{*}{$\begin{array}{l}\text { - forested } \\
45 \%\end{array}$} \\
\hline & 2014 & - & - & - & - & \\
\hline \multirow[t]{2}{*}{ Sesu cald } & 1990 & 12 & 100 & $\begin{array}{l}\text { 250- villagers sheep } \\
\text { 3000- coming from plain }\end{array}$ & 12 & \multirow{2}{*}{$\begin{array}{l}\text { - forested } \\
30 \%\end{array}$} \\
\hline & 2014 & - & - & - & - & \\
\hline \multirow{2}{*}{ Buhuia } & 1990 & 3 & 18 & 10 & 4 & \multirow{2}{*}{$\begin{array}{c}\text { - forested } \\
75 \%\end{array}$} \\
\hline & 2014 & - & - & - & - & \\
\hline \multirow{2}{*}{$\begin{array}{l}\text { Izvoară or } \\
\text { Muntele Baisorii } \\
\text { Resort }\end{array}$} & 1990 & 13 & 65 & 60 & 2 & \multirow{2}{*}{$\begin{array}{l}\text { - forested } \\
10 \%\end{array}$} \\
\hline & 2014 & 7 & 32 & - & 2 & \\
\hline
\end{tabular}

household. Transhumance had a glorious past, is currently modest and may (or not) and a future. (MIRELA CIREBEA, 2011) (Table 6).

\section{CONCLUSIONS}

The study emphasizes that community while Baisoara significant changes have occurred in the category of land use, livestock and degree of depopulation of villages.

The number of animals decreased and also a large part of natural pastures were abandoned after that have forested (it is obvious phenomenon of sub-grazing).

The use of integral grasslands from mountain area has ensured life and prosperity a denser population than at present until the 1990s, after which there is a progressive and general abandonment of grassland due to halving the number of cattle and sheep.

The abandonment on grasslands produces great losses of the national economy underload up to abandonment, followed by the return the woody vegetation, the shrubs and forest, with which generations of mountaineers have struggled to maintain grasslands for normal state livestock.

The practice of transhumance is economically justified by the profit achieved by improving livestock feeding and grassland ecological fertilization and keeping valuable herbaceous vegetation.
The number of animals decreased and also a large part of natural pastures were abandoned after forested (it is obvious phenomenon of undergrazing).

Our study in this commune showed a dangerous tendency demographic and agricultural development.

The obtained results showed a close relationship between grassland status and the number of animals, which led us to the conclusion that the level of intensification of the crop system determines the direction of its evolution.

The most important influencing factor in the ecological mountain balance is represented by the man, the farmer - traditional animals breeder.

\section{REFERENCES}

1. Cirebea Mirela (2011). Natural and human landscape of the commune Băişoara, Bachelor paper, USAMV ClujNapoca.

2. Hopkins A. (2011). Mountain farming in Europe, Grassland farming and land management systems in mountain regions, Grassland Science in Europe, vol.16

3. Pötsch E., B. Krautzer, A. Hopkins (2011). Grassland farming and land management systems in mountain regions, Grassland Science in Europe, vol.16

4. Surd V., V. PuiU, V. Zotic, C. Moldovan (2007). Riscul demografic în Munţii Apuseni, Ed. Presa Universitară Clujeană, pag. 95. 
5. *** (1980). National Evaluation on the number of people and houses from Cluj area. Central department of statistics from Cluj-Napoca.

6. *** (2013). P.U.G. and R.L.U. of Băişoara commune.

7. ***, Central department of statistics from Cluj-Napoca.
8. *** (2013). Local document of Băișoara commune, Cluj County,

9. *** (2013). P.U.G. and R.L.U. of Băișoara commune.

10. *** (2013). Statistic notebook of Baisoara commune,. Central department of statistics from Cluj-Napoca. 